http://dx.doi.org/10.1590/1980-436920150001000049

\title{
A Produção da "Música Cabocla": a polifonia formadora do Carimbó nas representações de literatos, jornalistas e folcloristas no Pará (1900-1960)
}

Yielding the "Caboclo Music": the polyphonic creation of Carimbó through the accounts of writers, newsmen and folklorists in the Pará State (1900-1960)

\author{
Antonio Maurício Dias da COSTA \\ UFPA - Universidade Federal do Pará \\ Contato: makosta@pq.cnpq.br
}

Resumo: Este texto aborda o percurso histórico de debates artísticos e intelectuais desenvolvidos em torno da transformação do carimbó em expressão típica da musicalidade cabocla do Pará e da Amazônia. O intercâmbio de ideias entre folcloristas, jornalistas e escritores promoveu, entre $1900 \mathrm{e}$ 1960, os sentidos que se articularam em torno da ideia do carimbó como manifestação folclórica tipicamente regional.

Palavras-chave: Carimbó; Música Cabocla; Folclore; Representação; Polifonia.

\begin{abstract}
This text approaches the historic path of artists' and thinkers' discussions around the emergence of carimbó as a typical instance of caboclo music within the Amazon and the state of Pará. The exchange of ideas between folklorists, newsmen and writers, between 1900 and 1960, are presented here as an endorsement to the connection of senses related to the idea of carimbó as a typical expression of regional folklore.
\end{abstract}

Keywords: Carimbó; Caboclo Music; Folklore; Representation; Polyphony.

O carimbó ganhou as páginas do Jornal do Brasil na edição de $1^{\circ}$ de setembro de 1975 . O texto do jornalista Ribamar Fonseca intitulado Quando toca o carimbó, ninguém fica parado reportava a "descoberta" do ritmo em Belém, apresentado "pela primeira vez na cidade em 1958". As primeiras linhas do artigo são categóricas: “De repente, um ritmo do folclore local, até 1971 praticamente desconhecido dos próprios paraenses, explodiu nos salões, ganhou as ruas, chegou ao rádio e à indústria do disco, através de mais de uma dezena de gravações de conjuntos locais" (FONSECA, 1975).

A expressão musical é apresentada no texto como resultado do sincretismo entre culturas africana, portuguesa e indígena que se revelaria em seu nome, nos instrumentos e na dança. Desta síntese, viria à tona a música mestiça do "caboclo da Amazônia". E, para o autor, a visibilidade urbana 
do carimbó teria data de nascimento: o ritmo fora o centro de uma homenagem ao cônsul norteamericano em Belém, George T. Colman, ocorrida no Centro Cultural Brasil Estados Unidos em 1958.

A folclorista paraense Maria Brígido trouxe para o evento um grupo de música e dança de carimbó do município de Marapanim, localizado na região do litoral atlântico paraense, também conhecida localmente como o "Salgado". O grupo era dirigido pela própria folclorista, e sua existência indica a ocorrência de relações próximas entre grupos musicais folclóricos e pesquisadores de folclore em fins dos anos 1950 no Pará. Aliás, o grupo de Maria Brígido se fez presente também mais tarde em outra homenagem, que teria ajudado na definitiva difusão do carimbó em Belém: a recepção ao Ministro do Interior Costa Cavalcanti, em 1971, na sede da agremiação esportiva Tuna Luso-Brasileira. Na matéria, a folclorista desempenha um papel central na promoção do carimbó em eventos importantes relacionados a personagens destacadas do mundo político.

Outro exemplo de folclorista promotor de manifestações folclóricas citado no texto é o maestro Adelermo Matos. Assim como Maria Brígido, Matos dirigia um grupo folclórico dedicado a apresentações de carimbó, com a particularidade de ser um conjunto escolar de Belém. O grupo folclórico do Colégio Augusto Meira teria em seu currículo apresentações em "várias capitais, inclusive no Rio". Nos dois casos, segundo a matéria, temos a atuação de dois pesquisadores de carimbó na orientação de manifestações culturais entendidas amplamente como populares.

O carimbó foi anunciado naquela edição do Jornal do Brasil como novidade em Belém, em salões de escolas e num concurso promovido pela Prefeitura de Belém. No entanto, já se destacava um alerta dos próprios folcloristas quanto à mercantilização do ritmo. O texto falava em protestos dos folcloristas locais por causa da “deturpação da música”, especialmente promovida por gravações com "letras sofisticadas" presentes em LPs e nas apresentações de conjuntos musicais em clubes recreativos da cidade.

A defesa da autenticidade do carimbó foi a bandeira levantada por estes folcloristas, exatamente no momento em que a música começava a ser difundida pela imprensa nacional como representativa da cultura regional paraense e amazônica. Ao lado da atuação de músicos e cantores de carimbó, com seus LPs e apresentações ao vivo, os folcloristas tornaram-se promotores da reflexão sobre a música como expressão cultural regional, como se observa na matéria citada.

Este caso parece corresponder, à primeira vista, à formulação proposta por Roger Chartier (1995, p. 179) de que, antes de tudo, “cultura popular é uma categoria erudita”. Mas é necessário, neste como em outros exemplos, atentar para os sentidos vigentes no contexto histórico em questão relativos às manifestações estudadas e/ou promovidas pelos “eruditos". Há um percurso histórico 
particular dos termos folclore e cultura popular no debate de intelectuais no Pará desde meados do século XIX até os anos 1970, década da matéria citada.

Pretendo seguir neste artigo uma parte deste percurso, especificamente aquele em que se desenvolveram os meios de comunicação de forma mais intensa a partir do século XX até os anos 1960. Ao longo deste período, os estudos de folclore foram assumindo gradualmente um perfil intelectual-profissional definido, embora à margem do establishment acadêmico das universidades. Os limites deste recorte cronológico serão aqui, vez ou outra, ultrapassados em decorrência de exercícios comparativos, de modo a enriquecer a análise. Assim, será possível compreender a inserção do carimbó, enquanto "música típica do caboclo amazônico", na pauta dos debates de estudiosos do folclore e em suas interações com músicos, escritores e jornalistas.

De meados do século XIX a meados do século XX, o termo popular ganhou diferentes sentidos nos estudos de literatos e folcloristas na Europa e nas Américas. De manifestação da "alma nacional" e costumes camponeses, o popular folclórico assumiu gradativamente o sentido de expressão da tradição como sobrevivência no presente (ORTIZ, 1992, p. 05, 06, 25, 26). Nos dois casos, o popular emerge como um todo homogêneo, sem conflito, na forma de criações culturais de uma comunidade imaginada primitiva.

Trata-se, então, de uma trajetória de construção de sentido em que a ideia de cultura popular se associa a uma espécie de herança passadista, sempre em choque com o "processo civilizatório" (ORTIZ, 1992, p. 63). Daí assumirem os folcloristas o papel de guardiões preservadores da autenticidade de manifestações por eles tomadas como representativas da cultura popular. Tal missão intelectual ganhou escopo político e institucional exatamente no contexto de expansão e especialização do mercado cultural no século XX. Este desenvolvimento se deu por meio da produção e do consumo massivo de publicações impressas, de obras de artes plásticas, de espetáculos de performance artística, da produção fonográfica, de programas radiofônicos e televisivos (ORTIZ, 1992, p. 63).

No caso brasileiro, há duas fases distintas na história dos estudos de folclore (CAVALCANTI, 2012, p. 73-74). Na primeira, iniciada em meados do século XIX e que se estendeu até os anos 1940, artistas e literatos desempenharam centralmente o papel de inventariantes de manifestações culturais populares como representativas da nacionalidade. A segunda fase começou em 1947, com a criação da Comissão Nacional de Folclore (CNF), órgão nacional ligado à UNESCO e dirigido pelo musicólogo e folclorista Renato Almeida. Com a comissão, os estudos de folclore ganharam uma referência institucional e de profissionalização, ampliada por iniciativas do órgão, como a criação da Campanha de Defesa do Folclore Brasileiro (em 1958) e a publicação da Revista Brasileira de Folclore (a partir de 1960). 
Segundo Figueiredo (1998, p. 302), os estudos de folclore se iniciaram no Pará, na segunda metade do século XIX, em busca de manifestações regionais (lendas, crenças e costumes) que apontassem um ângulo particular e legítimo da história nacional. Esta perspectiva fortaleceu-se com o interesse dos intelectuais modernistas, a partir dos anos 1920, pela busca de uma linguagem nacional para as artes produzidas no País (CAVALCANTI, 2012, p. 94-95). Com isso, o tema da brasilidade passou a se sustentar na ideia de unidade das manifestações folclóricas regionais.

O folclorismo representava, neste contexto, o ponto de vista dos "eruditos" - literatos e artistas de formação acadêmica - sobre um espectro variado de manifestações culturais, dentre crenças e rituais religiosos, mitos e lendas, danças e cantos, musicalidade e folguedos. A inclinação mais geral dos pesquisadores do folclore era de abordar estas manifestações diversas como se fossem um complexo coerente, como um saber a ser difundido não só pela tradição, mas também por meio da educação formal.

O envolvimento de folcloristas com o universo do que compreendem como "cultural popular" implica, por sua vez, um posicionamento ambivalente de promotores de manifestações culturais em sua autenticidade e, ao mesmo tempo, de pesquisadores de um objeto "científico". Tal ambivalência explica a "acidentalidade metodológica" do folclore como campo de pesquisa e sua inadequação histórica ao meio acadêmico (ORTIZ, 1992, p. 30-32).

De todo modo, o desenvolvimento dos estudos de folclore acompanhou de perto o progresso das ciências sociais no século XX. Belmont (1986, p. 262) aponta a particular aproximação entre folclore e etnologia na França desde fins do século XIX. O uso da noção de sobrevivência entre os folcloristas franceses, para a coleta e estudo de produções populares, exemplifica esta aproximação. Sobrevivência torna-se sinônimo de relíquia e de resíduo, característica das expressões culturais verdadeiramente autênticas (BELMONT, 1986, p. 263-264).

Portanto, o mérito pela descoberta das relíquias culturais caberia ao expert do folclore, supostamente dotado de um entendimento mais amplo da riqueza das manifestações do que seus próprios promotores. A curiosidade do pesquisador lhe desperta o desejo por encontrar "sentidos" para expressões culturais. Belmont (1986, p. 266) fala em “desejo” para se reportar à sedução que os objetos de folclore exercem sobre o pesquisador em vista de sua aparente irracionalidade. À medida que aplica sua "cultura letrada" na tradução das manifestações classificadas como populares, o pesquisador produz novos sentidos, intercambiados com os sentidos nativos e aptos a apreciação nos meios intelectuais.

Nestes termos, observo a polifonia em torno do carimbó atravessada por clivagens de classe social: o mundo da maioria dos pesquisadores folcloristas não era o mesmo dos músicos de serenatas (CORRÊA, 2010, p. 87), dos batuques de terreiros afrorreligiosos, dos currais de bois-bumbá e das 
rodas interioranas de carimbó. A distância era maior no caso de literatos, jornalistas e folcloristas oriundos de famílias brancas e abastadas, moradores dos bairros centrais de Belém. Tal distância se revela em discursos e em práticas relativas às manifestações folclóricas, sempre representadas como a cultura do "outro", do exótico, do iletrado (FIGUEIREDO, 1998, p. 305).

Estas condições estão presentes nas entrelinhas das fontes aqui utilizadas: os poemas, as crônicas, as letras de canção, as notícias de jornal, os registros memorialísticos, dentre outros, revelam as trilhas de interlocução que deram origem aos sentidos enunciados. Além disso, o emprego destas fontes implica o conhecimento das condições histórico-contextuais em que foram produzidos estes sentidos na forma de representações.

Emprego a noção de representação como projeção social de discursos e ações que revelam interesses situados num campo de concorrência e competição entre frações da sociedade (CHARTIER, 2002, p. 17). Em outras palavras, a enunciação de sentidos para o folclore corresponde, em última instância, à afirmação social dos enunciadores como porta-vozes e guardiões de versões "autênticas" do que entendem como cultura popular. Este artigo destaca, por exemplo, como artistas e jornalistas obtiveram alguma projeção de suas obras e pontos de vista, quer afirmando as proposições dos folcloristas ou delas divergindo.

Os textos de memorialistas, por exemplo, falam mais de sua avaliação sobre o lugar social ocupado pelo carimbó no tempo de produção do escrito do que sobre o tempo a que se refere a memória. Da mesma forma, as notícias de jornal, os estudos de folclore, as crônicas e os poemas revelam aspectos do contexto histórico das publicações, ao destacar a posição social dos autoresenunciadores e seus interesses de interlocução com outros sujeitos.

Em determinadas situações, estes autores-enunciadores aparecem como mediadores culturais, isto é, como sujeitos que vivem diferentes papéis sociais (VELHO, 2001, p. 25), como entusiastas do folclore ou estudiosos. Em alguns casos, os mediadores podem ocupar uma posição ambígua e de transição entre mundos sociais diferentes (VOVELLE, 2004, p. 214). Os excertos textuais e demais registros aqui analisados como fontes apresentam exemplos de situações de mediação cultural. Nestas circunstâncias, as vozes de mediadores e de demais sujeitos são consideradas em razão de seus interesses e de posições sociais ocupadas. Aqui há o interesse em conhecer não só o que testemunham essas vozes, mas também sobre quem elas testemunham (VOVELLE, 2004, p. 224).

Vejamos então de que forma estas diferentes vozes, nem sempre consonantes, coincidiram na promoção do carimbó como a música característica do caboclo amazônico no Pará do início do século XX até o final dos anos 1960.

\section{O Carimbó nas visões de pesquisadores e de autoridades públicas}


A Produção da "Música Cabocla": a polifonia formadora do Carimbó nas representações de literatos, jornalistas e folcloristas no Pará (1900-1960)

A catedrática de folclore brasileiro da Escola Nacional de Música, Dulce Lamas, empreendeu uma viagem de pesquisa de um mês ao Pará em meados dos anos 1960. O relato sobre a viagem foi feito por meio de carta endereçada ao presidente do Conselho Nacional de Folclore, Renato Almeida. ${ }^{1}$ Pelo fato de a carta não conter datação, somente se pode deduzir o período da pesquisa a partir da referência ao contato da pesquisadora com o governador do Pará à época, o coronel Jarbas Passarinho. O militar fora empossado no governo após cassação do governador eleito Aurélio do Carmo, efetivada pela ditadura instituída no País a partir de 1964.

$\mathrm{O}$ fato de a viagem de pesquisa da folclorista iniciar com uma audiência com a autoridade político-militar maior do estado é revelador: sua movimentação entre o arquipélago do Marajó e Belém, em busca de registros sonoros de manifestações culturais, ocorreu com o decisivo suporte de autoridades políticas e de personalidades da elite econômica e intelectual local. Foi nestas condições que Dulce Lamas teve contato com apresentações de carimbó, boi bumbá, cordões de pássaro, ${ }^{2}$ quadrilha e festas de mastros de santos.

A viagem foi justificada pela ausência de registros do norte do País no acervo do Centro de Pesquisas Folclóricas da Escola Nacional de Música. A pesquisadora fala do seu interesse pelas "tradições de nossa gente", como uma forma de objetivação do que entendia como cultura nacional. Em outras palavras, registrar estas tradições folclóricas significava, neste sentido, incorporá-las como bens ao patrimônio cultural do País (GONÇALVES, 1996, p. 23).

Lamas foi apresentada pelo chefe do Serviço Médico da capital ao governador do Estado, que escreveu de "próprio punho" uma recomendação ao presidente da Cooperativa de Pecuaristas do Marajó para que a folclorista fosse acolhida em uma fazenda do arquipélago. Neste ínterim, o diretor da Faculdade de Odontologia de Belém já havia providenciado a hospedagem da pesquisadora na Fazenda "Santa Cruz da Tapera", nas imediações do município de Soure. Naquela cidade, Lamas foi auxiliada pelo Bispo do Marajó na "localização dos portadores da cultura do folk". Mas foi decisiva a ajuda do prefeito da cidade, que organizou uma apresentação de carimbó em frente ao principal hotel da cidade para que a pesquisadora pudesse fazer seu registro.

A montagem do evento para pesquisa demandou gastos da prefeitura com pagamento de dançarinos e tocadores, seu transporte e oferta de bebidas alcoólicas. Do ponto de vista da pesquisadora, mais importante que discutir os elementos propriamente musicais (ou de logística) do carimbó foi descrever seus componentes performáticos: instrumentos (especialmente os tambores), coreografia e trajes. Duas dançarinas, em particular, chamaram a atenção de Dulce Lamas: a "velha Tomásia, que diziam ter 100 anos" e era "muito animada na dança"; e Odete, uma "mulata benzedoura muito conhecida e solicitada em Soure". 
Importante é observar que Lamas se referia às mulheres em questão somente pelo primeiro nome, bem diferente de suas menções aos senhores e doutores, que contribuíram para sua estada em campo, com nomes e sobrenomes. Odete, em particular, ganhou a atenção da pesquisadora por ser dona de um barracão onde organizava bailes dançantes aos sábados, nos quais era dançado o lundu. O interesse da pesquisadora pelas festas do barracão de Odete foi obstado pela solicitação do prefeito de que a folclorista não fosse àquele lugar, "por considerá-lo ambiente impróprio". Por fim, Lamas disse ter acedido à solicitação para não constranger o prefeito.

Este acontecimento é sumamente revelador da postura ambígua de muitas autoridades públicas locais perante manifestações lúdicas e artísticas como o carimbó, em meados do século XX. De um lado, o evento preparado pelo prefeito em frente a um hotel da cidade serve como exemplo propício das "tradições do nosso povo", enquanto relíquia, sobrevivência folclórica. Por outro lado, eventos dançantes, como os do barracão de Odete, que escapavam ao controle estrito das autoridades públicas eram apresentados como impróprios, talvez por estarem muito dentro dos domínios do popular. No segundo caso, o ambiente característico do carimbó e do lundu, conduzido por gente comum como Odete, é visto por membros da elite política de Soure como perigoso, não recomendável para a realização de pesquisa folclórica, especialmente por ser uma mulher a pesquisadora.

Ao recuarmos no tempo, tende a se aprofundar tal distanciamento entre o mundo das autoridades públicas e das pessoas comuns do povo, em torno de manifestações como o carimbó. É o caso do Código de Posturas Municipais de Belém que, entre os anos 1848 e 1880, manteve um artigo com a proibição de "[...] fazer batuques ou sambas, [...] tocar tambor, carimbó, ou qualquer outro instrumento que perturbe o sossego durante a noite" (CÓDIGO, 1848 e 1880) - sob pena de pagamento de multa.

A presença deste artigo na legislação municipal em Belém durante quase toda a segunda metade do século XIX pode ser lida pelo que indica de forma inversa: batuques, sambas e carimbós faziam-se efetivamente presentes como manifestações musicais e de dança na cidade, provavelmente realizadas por negros e mulatos em eventos como carnaval, festas juninas ou em comemorações de amigos, parentes e vizinhos.

Vicente Salles (2004, p. 200-202), por exemplo, aborda a presença do lundu no Pará desde o início do século XIX a partir de impressões de viajantes europeus sobre a região. Segundo essas impressões, o lundu seria uma espécie de samba de roda, também chamado batuque, praticado por negros em festins populares, como nas comemorações profanas das festas de santo. Na interpretação do folclorista, a larga repercussão do lundu ao longo do século no Pará teria dado origem a “numerosas danças locais”, dentre elas, o carimbó (SALLES, 2004, p. 211). 
Estes dados ajudam-nos a entender a associação do carimbó, como uma forma de batuque, com o universo lúdico musical do negro no Pará no século XIX. Ao longo deste período ocorreram crises políticas e sociais como a Cabanagem, a abolição da escravidão e o final da Monarquia. A dança-música negra seguiu por este século como um elemento do mundo dos desclassificados. Daí sua presença na cidade ser tratada nesta época como caso de polícia.

Do ponto de vista de literatos paraenses do início do século XX, o carimbó poderia suscitar interesse por sua vinculação às populações do interior do estado. É o caso do vocábulo "carimbó", descrito pelo fazendeiro e naturalista paraense Vicente Chermont de Miranda em seu "Glossário Paraense" (MIRANDA, 1968). O livro, publicado originalmente em 1905, posteriormente ganhou uma nota biográfica escrita pelo filho do autor em 1942. Na nota, Miranda é apresentado como homem de origem aristocrática, com experiência de estudos na Europa, dono de engenho de açúcar herdado dos pais, cartógrafo e botânico, ocupante de mandatos políticos durante o Império como deputado provincial e intendente de Belém e autor de dois livros sobre o Marajó.

No prefácio da edição de 1905, Miranda informa que o livro fora escrito nas horas de lazer em suas fazendas, provavelmente resultando do cotidiano de contatos com trabalhadores de suas propriedades. Segundo ele, a obra buscava divulgar a "linguagem popular, usada correntemente pela população rude e sensual dos nossos sertões". A população "rude e sensual" à qual o autor se refere corresponde provavelmente ao contingente destacado de camponeses negros e mulatos de suas fazendas da região do Rio Capim, importante núcleo de produção açucareira no Pará desde o século XVII. ${ }^{3}$

A presença marcante da população negra na região certamente contribuiu para o painel demográfico apresentado por Miranda, relativo ao Pará. Sem identificar a fonte dos dados mencionados, o autor aponta a presença de 37\% de "sangue africano" na população paraense, equiparando-se à parcela de 37\% de "sangue tupi” (MIRANDA, 1968, p. xii). Por isso, a definição de "manifestações culturais populares" presentes no glossário supõe a vinculação de expressões lúdico-artísticas com matrizes negras e indígenas. No texto, o carimbó (tambor), associado à dança do batuque, é uma expressão de origem africana, "importada pelos negros cativos".

Instrumento, dança ou música, o carimbó se fazia vivo na cidade Belém do início do século $\mathrm{XX}$, mas despertava pouco interesse intelectual. O violonista negro Tó Teixeira, morador do bairro do Umarizal, compôs um carimbó para um cordão carnavalesco de seu bairro em 1908. Entre aquela data e o ano de 1916, Teixeira participou do cordão "Pretinhos de Moçambique", entre seus 15 e 23 anos de idade (HABIB, 2013, p. 41). A composição foi guardada pelo violonista como partitura, até que a parceria intelectual com o folclorista Vicente Salles, iniciada nos anos 1960, viesse a 
impulsionar o conhecimento público desta sua obra. A partir daquela década, muitas informações do violonista sobre o cenário musical belenense, por ele muito conhecido, trouxeram benefício a Salles.

Tais informações foram incluídas em vários livros de Salles sobre a história da música no Pará (SALLES, 1970, 1980, 1981, 1985, 2005) e servem de base para estudos de outros pesquisadores. É o caso do livro do violonista Salomão Habib sobre a trajetória de Tó Teixeira, publicado em 2013. A obra escrita é acompanhada de discos e vídeos com composições de Teixeira gravadas (em CD) pela primeira vez, com execução de Habib. É apresentado nesta coletânea o carimbó dos "Pretinhos de Moçambique", com a performance do violão solo de Habib e foco na melodia curta, dançante, possivelmente usada como base para a execução percussiva e a variação de estrofes improvisadas durante o cortejo.

Os cordões carnavalescos eram em geral oriundos de bairros suburbanos de Belém, e seus cortejos foram presença marcante nos carnavais da cidade durante as três primeiras décadas do século XX. Segundo Corrêa (2008, p. 15-17), eles eram compostos por homens fantasiados de personagens (rainha do batuque, índio, embaixador, intérprete, feiticeiro, porta-estandarte, baliza) ao som de chocalhos, tambores, pandeiros, clarinetes, com que tocavam lundus, maxixes, quadrilhas e sambas. O escritor De Campos Ribeiro, em seu livro de memórias de Belém lançado em 1966, relata que cordões de pretinhos (como o "de Moçambique") eram compostos "quase na totalidade de negros", vestidos com "trajes selvagens", portando "títulos de fidalguia" e que "cantavam e dançavam lundus, tocavam pandeiros, atabaques, chocalhos" (DE CAMPOS RIBEIRO, 2005, p. 18).

Vale dizer que estas são impressões registradas na memória de infância do autor, ${ }^{4}$ dos anos 1900 e 1910, e que foram atualizadas à época da comemoração do $350^{\circ}$ ano da fundação de Belém. O autor obteve espaço pela efeméride para, com apoio do governo estadual, publicar sua obra comemorativa da história da cidade. Mas eventos que eram em 1966 reminiscência de uma "gostosa Belém de outrora”, para o autor, foram objeto de preocupação policial nas décadas iniciais do século. Os cortejos oriundos do subúrbio exaltavam rivalidades entre bairros quando seus percursos se cruzavam pela cidade durante o carnaval. Os encontros de cordões poderiam render enfrentamentos físicos e intervenção policial (CORRÊA, 2008, p. 09; LEAL, 2008, p. 191). Nestes casos, o repertório performático dos cortejos tendia a ser associado pelas autoridades à desordem pública e à criminalidade.

Esta avaliação é feita de forma clara em uma carta publicada no jornal Estado do Pará, na edição de 13 de janeiro de 1913, coluna Tópicos e Notícias (ESTADO DO PARÁ, 13/01/1913, p. 13). A missiva dos moradores da "rua dos Tamoyos, entre as travessas de Breves e Monte Alegre", no bairro do Jurunas, buscava atrair a atenção das autoridades públicas para o inconveniente de festas dançantes com carimbó, em uma casa da vizinhança. Os participantes são nomeados e apresentados 
como uma "malta de desclassificados", na maioria negros e mulatos, não se poupando qualificações como "lugar de desocupados e vagabundas", "espaço de danças macabras e brigas". A casa também é apresentada como lugar onde "campeia grande feitiçaria”. Os autores solicitavam repressão policial, seguindo a linha prescritiva do artigo 107 do código de posturas municipais ("Das Bulhas e Vozerias"), que proibia batuques e sambas, de modo a garantir o sossego público.

Em suma, bailes de carimbó na vizinhança da rua dos Tamoyos nos anos 1910, como possivelmente ocorria em outros bairros suburbanos à época, podiam ser denunciados na imprensa como lugar de "desclassificados", de desordem e de feitiçaria, mesmo que ocorressem em espaços de práticas religiosas como terreiros de batuque, ${ }^{5}$ como parece ser o caso. Nada mais distante da visão condescendente de autoridades públicas paraenses sobre o carimbó nos anos 1960 como exemplo de "tradição de nossa gente".

Neste caso em particular, o jornal Estado do Pará, assim como outros diários belenenses do início do século, davam destaque a este tipo de notícia tanto por sua repercussão entre os leitores e venda de jornais quanto pelo alinhamento dos editores com o que era avaliado como defesa do sossego público. De todo modo, o carimbó dos “desclassificados" da rua dos Tamoios chamava tão pouca atenção dos interessados pelo folclore regional paraense em 1913 quanto os carimbós executados em cordões carnavalescos, como o que fora composto por Tó Teixeira cinco anos antes.

$\mathrm{Na}$ verdade, estas manifestações ocupavam espaços marginais na sociedade belenense da época, especialmente do ponto de vista de autoridades públicas e de alguns editores de jornais diários. Exemplar é a mesma reprovação social estampada na imprensa paraense algumas décadas antes, embora sem menção particular ao carimbó. Vicente Salles (1971, p. 189) menciona a existência de "sambas urbanos" no bairro do Umarizal em fins do século XIX, dado obtido em uma nota publicada no jornal Diário de Belém, de 18 de setembro de 1884. Segundo o autor, o texto apresentava reclamações de moradores do bairro Umarizal contra batuques/sambas realizados à noite. Assim como a carta de 1913 do Estado do Pará, a nota de 1884 do Diário de Belém "pedia providências à polícia, a fim de proibir esses sambas noturnos", com "tambores e pandeiros e gritos" (DIÁRIO DE BELÉM, 18/09/1884).

A partir dos anos 1920, surgiram em Belém novas avaliações sobre o carimbó em escritos de literatos, em revistas e jornais. Crônicas, poemas e textos de opinião passaram a promover novos sentidos para a música/dança local, distanciados de referências ao mundo dos "desclassificados" ou a atentados ao sossego público.

\section{O Carimbó e a Vanguarda Literária Paraense dos anos 1920-30}


O historiador Aldrin Figueiredo (2012, p. 18-19) apresenta o movimento literário paraense surgido em meados da década de 1910 como a defesa de jovens literatos de um "novo projeto de nação". Apesar das diferenças intelectuais, políticas e de origem social dos literatos, eles tomavam as redações de jornais e revistas de Belém do início do século XX como um terreno comum. Além disso, seus escritos tendiam a promover a figura do "homem mestiço da Amazônia" como tipo social característico e matriz da identidade cultural regional.

A identificação do mestiço regional, o caboclo, como referência social e cultural amazônica relacionava-se, segundo Figueiredo (2012, p. 23), com a promoção de um aspecto da identidade nacional sob o ângulo do norte do País. Para o historiador, esse é o denominador comum de poemas, contos, crônicas e estudos dos literatos paraenses que se agruparam em sociedades literárias desde 1916 e se reuniram principalmente na Associação dos Novos, criada em 1921 (FIGUEIREDO, 2012, p. 21-22).

Marcos históricos orientaram e reforçaram a organização dos grupos literários belenenses até a vigência da Associação dos Novos: o tricentenário da fundação de Belém (em 1916) e o centenário da adesão do Pará à independência do Brasil (em 1823). Ao mesmo tempo, a criação de revistas literárias como A Semana (em 1918) e Belém Nova (em 1923) estipulou núcleos básicos de atuação dos literatos, completados pelo trabalho em jornais diários e pela produção de livros (FIGUEIREDO, 2012, p. 17, 21-22). Com a consolidação de sua projeção jornalística e literária, tornava-se mais fácil para os "Novos" buscarem colocações na burocracia do estado e ingressarem na carreira de professor (FIGUEIREDO, 2012, p. 49).

É com este pano de fundo que devemos entender o projeto intelectual e artístico destes escritores: "derrubar os monumentos da literatura e das artes" (FIGUEIREDO, 2012, p. 48) e, ao mesmo tempo, produzir uma linguagem literária baseada nos "costumes da Amazônia" (FIGUEIREDO, 2012, p. 29). O objetivo seria promover uma nova identidade nacional sob ângulo regional. E constituiriam a matriz para isso o mundo social e as criações culturais do caboclo amazônico.

O manifesto literário que representa esta perspectiva de modo categórico foi publicado em 1927 pelo poeta Abguar Bastos e intitulava-se Flami-n'-Assú, associação do termo latino para "chama” com o sufixo tupi "açu”, grande. A "Chama Grande” culturalmente mestiça de Bastos veio a público na edição 74, de 15 de setembro de 1927, da Belém Nova. Bastos apresenta o texto como "manifesto aos intelectuais paraenses" e nele propõe a "índole nacional" como fundamentalmente mestiça: “Flami-n’-Assú é mais sincera porque exclui, completamente, qualquer vestígio transoceânico; porque textualiza a índole nacional; prevê as suas transformações étnicas" (BASTOS, 15/09/1927). 
No mês seguinte, apareceu na mesma Belém Nova um poema do escritor Teixeira Monteiro, enviado do Rio de Janeiro e intitulado Bailado das Três Raças (MONTEIRO, 1927). Acompanhando o mesmo ponto de vista de Flami-n'-Assú, o poema de Monteiro destaca a batida do carimbó no terreiro como criação miscigenada, fruto das três raças, relíquia da "autêntica" matriz cultural brasileira: "Retumba, retumba, monótono, retumba / Ronca, ronca, no terreiro, o carimbó [...]".

A música monótona do caboclo está presente no poema entre "vozes bárbaras na floresta", em que convivem mestiços de africanos, índios e navegadores portugueses, mesclados à natureza agreste e de fortes odores. Por isso, o carimbó seria no poema uma mistura de jongo, poracé e fado, supostas matrizes musicais africanas, indígenas e portuguesas. Talvez como resultado da fusão, o carimbó é apresentado como um canto triste, mas que promove sensações prazerosas, expressão das emoções mais profundas da "síntese das três raças".

Segundo o poema, o lugar por excelência do carimbó é a floresta, e não cidades interioranas, o subúrbio de Belém ou as festas carnavalescas. A peça literária de Teixeira Monteiro se afinava com a orientação do "elogio da mestiçagem", perspectiva intelectual promovida por pesquisadores da formação social brasileira em fins dos anos 1920 e durante os anos 1930. Esta interpretação da formação brasileira ganhou sua maior expressão na obra Casa Grande e Senzala, de Gilberto Freyre (de 1933), e se tornou referência intelectual de artistas filiados a esta vertente (SCHWARCZ, 1995; COSTA, 2001).

Mas, como projeto político-intelectual, o papel da "mistura das três raças" na "formação das manifestações culturais autênticas" da nação se ajusta a uma ideologia de conciliação. Este discurso é analisado por DaMatta (1987, p. 68) como uma forma de posicionar grupos, parcelas sociedade, em um plano hierárquico e, portanto, desigual de relações sociais. Assim, o caboclo que vive entre as "vozes bárbaras da floresta" chama atenção como referência da nacionalidade e sobrevivência de um passado formador da nação. Sua música, o carimbó que "retumba monótono", atraía o interesse dos modernistas na forma de uma das matrizes do que concebiam como um projeto de nacionalização musical.

Não que os literatos paraenses tivessem estipulado uma pauta de pesquisa musical relativa a manifestações folclóricas ainda nos anos 1920. Isto teria que esperar a atuação de músicos de formação erudita nos meios intelectuais belenenses nos anos $1930 .{ }^{6}$ De todo modo, a avaliação dos literatos locais sobre manifestações folclóricas como a música não se distanciava do projeto de pesquisa artística musical de Mário de Andrade, ${ }^{7}$ que começou a ganhar corpo em fins dos anos 1920 (ANDRADE, 1928, 1929, 1934). ${ }^{8}$

Para o musicólogo e escritor paulista, a verdadeira música nacional expressa a alma do povo que a criou e só pode ser encontrada, em sua forma autêntica, no “ambiente popular", isto é, no mundo 
rural (TRAVASSOS, 2000, p. 33-36). Caberia então aos músicos de formação acadêmica, eruditos, recolher como "documentos" esta música associada ao cotidiano religioso, de trabalho e de lazer das populações rurais, de modo a transpô-la para a linguagem erudita. Assim, os compositores acadêmicos passariam a fazer música brasileira de forma "natural", "indo muito além da citação" (TRAVASSOS, 2000, p. 47).

Portanto, na visão de Mário de Andrade e de outros músicos e literatos brasileiros do seu tempo, a música rural, intuitiva, constituía um dos resíduos de primitivismo da cultura brasileira. $\mathrm{O}$ primitivo cultural corresponderia, então, às manifestações artísticas rurais ainda não desagregadas pela civilização urbana e seu mercado de entretenimento. A música primitiva, neste sentido, seria uma herança arcaica a ser documentada antes que viesse a desaparecer, de modo a desempenhar um papel pedagógico na formação do caráter nacional brasileiro.

Perspectivas semelhantes sobre a "arte primitiva" vigorava, por exemplo, no meio artísticointelectual francês na década de 1920. Clifford (1998, p. 136, 138, 144, 152) destaca a visão da vanguarda artística parisiense daquela década de que África, Oceania e América eram reservas de outras fontes estéticas exóticas frente ao racional, ao belo e ao normal do Ocidente. Segundo o autor, o desenvolvimento concomitante do surrealismo e da etnografia na França nos anos 1920 esteve vinculado à valorização estética do "nègre", que poderia significar coisas como máscaras tribais africanas, rituais do vodu haitiano, esculturas da Oceania e artefatos pré-colombianos (CLIFFORD, 1998, p. 156).

No caso brasileiro e modernista, o exótico valorizado eram as criações artísticas rurais e mestiças predominantemente. Em alguns poucos casos, a ênfase era dada às expressões culturais negras. Um dos líderes da Associação dos Novos nos anos 1920, o escritor negro Bruno de Menezes, nascido no bairro suburbano do Jurunas, lançou uma coletânea de poemas intitulada "Batuque" na edição 78 da Belém Nova, em 18 de agosto de 1928. Em 1931, a obra foi transformada em livro ${ }^{9}$ e, em 1954, conquistou um prêmio literário concedido pelo Governo do Pará. Desde então, "Batuque" tem sido uma das mais conhecidas e importantes obras do autor, dentre suas várias publicações de poemas, romances e estudos folclóricos.

A obra, de teor simbolista, de fluxo poético-narrativo que evoca a sonoridade de ritmos e timbres, está voltada para temas populares do universo cultural negro conhecidos pelo autor desde a infância (FIGUEIREDO, 2012, p. 111). Dentre os temas do livro de Bruno de Menezes, se encontrava o carimbó, mencionado no poema Alma e Ritmo da Raça: “[...] Não é candomblé não é 'Santa Bárbara' / Nem banzo banzado bom carimbó bolinoso; / - bailado benguela de gente sem nome / Que agora machuca as 'senhora' e os 'sinhô' [...]". 
A Produção da "Música Cabocla": a polifonia formadora do Carimbó nas representações de literatos, jornalistas e folcloristas no Pará (1900-1960)

O poema tem como personagem uma mulher negra, sem nome, que dança de forma sensual e tem um cheiro provocante, como fruta regional. São comuns neste e em outros poemas do livro equivalências entre beleza feminina negra e frutas regionais, ambas apresentadas como tentadoras para o homem branco, externo a este mundo. O poema menciona uma música de fundo, tocada com banjo e tantãs, que seria o "carimbó bolinoso", música-dança profana de sentido lúdico e sensual. O carimbó, que não é tocado com curimbó, mas com instrumentos comuns no lundu e nos sambas (banjo e tantãs), é apresentado pelo autor como a "alma e o ritmo da raça", que fora assimilada de forma clandestina pelos senhores brancos.

A sensualidade inerente à dança-ritmo oriunda da música negra corresponde, no poema, ao que há de exótico e, portanto, de primitivo no carimbó. A composição artística de Bruno de Menezes em "Batuque", para além dos elementos de erudição e técnica poética, é marcada pelas experiências vividas na infância, no Jurunas dos anos 1900, junto a bumbás, cordões de pássaro (SALLES, 1993, p. 15) e, certamente, execuções de carimbó. Em "Batuque", o carimbó é uma expressão de dança e música componente da lúdica negra existente no Pará.

Segundo Batista (2001, p. 11), os literatos modernistas paraenses dos anos 1920 eram entusiastas dos folguedos suburbanos de Belém. Carnaval, malhação de Judas, festas juninas, apresentações de boi bumbá, pássaros e pastorinhas constavam em seus versos, crônicas e romances. Em seus escritos, os folguedos suburbanos poderiam ser equiparados às manifestações folclóricas rurais, o que revestia a presença dos escritores nestes eventos de um sentido de coleta folclórica.

Batista (2001, p. 48 e 49) destaca, por exemplo, os trabalhos de assessoria de alguns literatos a grupos folclóricos nos anos 1920, especialmente voltados para a preservação de tradições como boi bumbá, banhos de cheiro e cordões carnavalescos. A defesa destas manifestações significava, para os literatos, divulgação de seus conteúdos e apresentações em revistas como A Semana e Belém Nova e nos jornais diários da cidade.

Travavam-se embates nas folhas dos periódicos, naquela altura, sobre a preservação de folguedos populares. Figueiredo (2012, p. 75 e 124) reporta a ocorrência, nos anos 1920, de uma disputa entre literatos na imprensa em torno da preservação dos "costumes paraenses", relativos aos folguedos carnavalescos e juninos. Neste debate, os cordões de pretinhos assumiam papel destacado entre os que defendiam ou não a manutenção de práticas carnavalescas antigas, oriundas da época do entrudo.

Mas o que era visto como exótico ou arcaico não estava tão distante do mundo dos literatos. Lembremos que, dez anos antes, o cordão Pretinhos de Moçambique desfilava nas ruas da cidade com um carimbó composto por Tó Teixeira. Neste caso, o sentido lúdico do carimbó associava-se à disposição festiva da agremiação carnavalesca suburbana. Nisto, a presença do carimbó na cidade se 
assemelhava muito ao que descrevia Bruno de Menezes em seus versos. Vale destacar que o poeta era amigo de Tó Teixeira, participou a seu lado de serenatas boêmias juvenis (CORRÊA, 2010, p. 84) e foi seu colega de profissão numa oficina gráfica em sua primeira experiência profissional.

Bruno de Menezes apresentou em 1928 o carimbó dança-música profana como "alma e ritmo da raça negra", mas outras visões eram propostas por literatos do seu tempo. Por exemplo, o jornalista José Coutinho de Oliveira elaborou uma definição de carimbó, na edição de 20 de dezembro de 1937 da Folha do Norte Vespertina, que o associava unicamente à religião. Apoiado na leitura de um artigo do escritor e advogado Levihall de Moura, publicado no mesmo jornal dois dias antes, Oliveira escreveu um texto em defesa da "macumba" e contra a repressão policial que terreiros e eventos afrorreligiosos vinham sofrendo na cidade.

O artigo, sinteticamente intitulado Macumba, apresentava a tese de Oliveira de que a macumba "significava um instrumento musical africano, usado nos batuques e danças dos escravos negros" e que passou a ser denominado carimbó, termo homólogo a batuque e a borocô. Este último termo, por sinal, fez-se presente em uma composição de Pixinguinha e Gastão Vieira, gravada pelo próprio Pixinguinha em 1938. A letra da canção situa de forma precisa o sentido de borocô como Nanã Buruku, entidade nagô dos candomblés de caboclo, associada às águas e aos pântanos (AMARAL; SILVA, 2006, p. 195).

O conhecimento do panteão do candomblé, estampado num samba de sucesso divulgado no mercado musical carioca em 1938, destoava da não familiaridade de José Coutinho Oliveira e de Levihall de Moura com este domínio religioso. Isto era patente, apesar da afinidade de jornalistas e literatos, como os citados acima, com a causa da religião africana no Pará nos tempos repressivos do Estado Novo varguista.

O texto de Levihall de Moura, já mencionado e intitulado Em Defesa das Macumbas, classificava as práticas afrorreligiosas como mero folguedo popular, diversão dançante como o samba e o carimbó. Do ponto de vista daquele escritor, advogado e militante comunista, este argumento funcionava como defesa da liberdade de culto, pela qual militou nos anos 1930, inclusive emitindo habeas corpus para mães e pais de santo ameaçados de prisão (LEAL, 2011, p. 203).

O tipo de engajamento de Moura, no entanto, não se repetiu entre muitos outros jornalistas belenenses naquela década. O jornal A Folha do Norte se manteve como frente opositora à interventoria estadonovista na imprensa local (LEAL, 2011, p. 82). O diário serviu como principal plataforma de atuação dos 25 intelectuais locais que apresentaram manifesto ao governo estadual, em novembro de 1938, em favor da liberdade religiosa constitucional.

Leal (2011) defende em sua tese o argumento de que o engajamento político de escritores, músicos e jornalistas se baseou em um interesse comum pelo que entendiam como cultura negra. A 
preocupação com a defesa das manifestações culturais negras no Pará, neste contexto, assinalou o desenvolvimento dos estudos folclóricos sobre o tema ${ }^{10}$ e seus desdobramentos nas décadas seguintes (LEAL, 2011, p. 18).

O interesse pelo carimbó como manifestação da cultura negra, enquanto nova perspectiva de estudo do folclore regional, foi também impulsionado pelo advento da Missão de Pesquisas Folclóricas, promovida pelo Departamento de Cultura da Prefeitura de São Paulo. Os folcloristas ligados ao projeto dirigido por Mário de Andrade realizaram pesquisa em Belém entre 27 de junho e 7 de julho de 1938. Na ocasião, fizeram registros sonoros e filmagens de boi-bumbá, babassuê e rituais de pena e maracá (MOURA, 1997, p. 33; VINCI DE MORAES, 2010, p. 07). Mas, alguns dias antes, a equipe havia gravado uma apresentação de carimbó em São Luís do Maranhão.

\section{O Carimbó e a Missão de Pesquisas Folclóricas}

O projeto idealizado por Mário de Andrade derivou de sua viagem ao Norte e Nordeste do País em 1928. Mário havia redigido o anteprojeto de criação da Secretaria do Patrimônio Histórico e Artístico Nacional em 1936 e pretendia, já naquela data, estabelecer um projeto de patrimonialização da música brasileira junto ao Ministério da Educação e Cultura (TONI, 2006, p. 25 e 27). Com a recusa do ministro, e ao assumir o cargo de diretor do Departamento de Cultura da Prefeitura de São Paulo, Mário de Andrade incorporou o projeto na pauta da Discoteca Pública do município em 1936 (TONI, 2006, p. 28).

A missão seria a viagem de pesquisa de uma equipe composta por folcloristas e músicos por estados do Nordeste e Norte do Brasil, voltada para a preservação do patrimônio musical "em desagregação", com gravações sonoras, fotografias e filmes. Tratava-se então de um projeto orientado para a constituição de um patrimônio cultural em torno da "retórica da perda": colecionamento, restauração e preservação frente a processos de destruição de manifestações da "cultura", da "tradição" e da "memória nacional” (GONÇALVES, 1996, p. 21 e 22).

Após um périplo por cidades e regiões interioranas de Pernambuco, Paraíba, Ceará e Piauí, a missão chegou à capital do Maranhão em 15 de junho de 1938 e lá permaneceu até o dia 21 daquele mês. O tempo da pesquisa fora encurtado em razão da posse de nova gestão na Prefeitura de São Paulo, que se mostrava desfavorável ao projeto de Mário de Andrade (TONI, 2006, p. 30).

Em São Luís, os pesquisadores mantiveram o critério de seleção das manifestações culturais empregado em outros lugares: assistir à apresentação preliminar para decidir sobre a gravação e o arranjo cenográfico e técnico empregado (TONI, 2006, p. 31). Estas foram provavelmente as condições estipuladas para a gravação de uma apresentação de carimbó ocorrida na capital 
maranhense. A filmagem realizada pelos pesquisadores em 19 de junho de 1938, no Bairro João Paulo (MISSÃO, 2013), teve um cenário montado com folhagem, tronco de árvore e painel branco ao fundo. O registro foi feito com uma câmera fixa, e a reprodução das imagens segue de forma relativamente acelerada.

A gravação apresenta um solo de voz e marimba (berimbau). Um homem toca berimbau com a batida característica, de frente para a câmera. Ele veste calça branca, camisa creme aberta com mangas, sapato branco e boné. Após a introdução instrumental, adentra a cena uma mulher negra, com chapéu de feltro e vestido branco, levantando as barras da saia do vestido. A mulher caminha em direção ao tocador de costas para a câmera. A dança é feita sempre segurando as barras da saia com requebros curtos, voltas completas à direita e à esquerda, acompanhadas de canto.

A canção, tal como o som do berimbau, parece ter sido gravada em outro momento e colada à filmagem. A cantiga é melancólica e aguda e repete várias vezes a mesma frase: "Ôo Marimbeiro, marimbeiro, que a tua marimba não ganha dinheiro”. Ao final, a dança torna-se mais rápida e então a gravação é encerrada abruptamente.

Neste exemplo de carimbó maranhense do final dos anos 1930, a partir do crivo da Missão de Pesquisas Folclóricas, a música é executada sem tambores, flautas ou qualquer instrumento semelhante. Trata-se de uma versão diferente dos carimbós paraenses do final do século XIX e início do século XX, sobre os quais as notícias aqui apresentadas mencionam tambores e violões. O fato é que as diversas expressões do que podia ser identificado como carimbó em diferentes situações ainda não perfaziam uma referência folclórica característica em fins dos anos 1930. Mas a missão de pesquisas folclóricas dava a sua contribuição para esta tendente caracterização artística e intelectual.

Em vista de sua orientação folclorística, a missão desprezava manifestações que expressassem relações entre criações de artistas populares e artigos difundidos pelos meios de comunicação. É o caso das gravações de toadas do Boi Pai do Campo, realizadas em Belém durante a permanência da missão na cidade entre 27 de junho e 7 de julho de 1938. Vinci de Moraes (2010, p. 08) afirma que estes registros foram marginalizados no acervo da missão por apresentarem reproduções e adaptações de sambas de sucesso no Rio de Janeiro dos anos 1930.

$\mathrm{Na}$ fase final da pesquisa, o grupo chegou a Belém exatamente no contexto de repressão às manifestações afrorreligiosas, prática institucional de alcance nacional no início do Estado Novo (TONI, 2006, p. 31). No caso de Belém, a presença da missão provavelmente ratificava a atuação dos escritores e jornalistas locais pela defesa da liberdade religiosa. Indício da ligação com sujeitos do meio literário local é o contato dos pesquisadores paulistas com o médico e escritor paraense Gastão Vieira. Conhecido de Mário de Andrade desde 1927, Vieira contribuiu na busca de manifestações 
A Produção da "Música Cabocla": a polifonia formadora do Carimbó nas representações de literatos, jornalistas e folcloristas no Pará (1900-1960)

folclóricas em Belém (TONI, 2006, p. 30), provavelmente orientando, dentre outras coisas, o registro das toadas do Boi Pai do Campo do bairro suburbano do Jurunas.

Mas a descoberta feita pelos pesquisadores no Jurunas lhes pareceu pouco auspiciosa: canções do mercado musical haviam sido apropriadas por um grupo folclórico regional e vertidas para um formato propício às apresentações de boi, próximas do batuque de carimbó. Segundo Vince de Morais (2010, p. 12), os registros pessoais dos membros da missão indicam o desapontamento com a descoberta e a constatação de "deterioração" de um tipo de manifestação folclórica paraense. Para o autor, os diretores da missão e seus pesquisadores desconsideravam as possibilidades de mobilidade cultural no campo da música criada por artistas do povo.

A divulgação de sambas de sucesso da Capital Federal nos folhetos da Revista Guajarina e nas apresentações teatrais do período da festa religiosa do Círio de Nazaré é exemplo de mobilidade cultural na Belém dos anos 1930. As músicas do cinema, do disco gravado e dos programas de rádio eram também popularizadas por estes meios. $\mathrm{O}$ teatro musicado e/ou revisteiro, particularmente, tinha temporadas regulares em datas festivas importantes do calendário da cidade à época: Carnaval, Festas Juninas, Círio de Nazaré e Natal (CORRÊA, 2010, p. 140).

Esta modalidade de teatro popular esteve muito próxima de cordões de pássaro e de boi bumbá entre os anos 1910 e 1940, por meio de seus autores, músicos e atores. Segundo Moura (1997, p. 42), os bumbás revelaram libretistas, músicos e intérpretes que passaram a se apresentar nas revistas da quadra nazarena. Mais ainda, o recurso da paródia estimulava o interesse das plateias pela burla de costumes e de temas políticos (CORRÊA, 2010, p. 140). Da mesma forma, as canções apresentadas nos espetáculos faziam-se também presentes nos repertórios de shows em bares e clubes e eram divulgadas nos folhetos da Revista Guajarina.

A Editora Guajarina, criada em Belém nos anos 1910, especializou-se na publicação de folhetos de cordel e de letras de canções populares. Segundo Salles (2005, p. 84), o repertório dos folhetos era composto por modinhas e outras criações de compositores regionais nos anos $1920 . \mathrm{Na}$ década seguinte, este repertório seria substituído por canções de sucesso de artistas cariocas, difundidas no disco e no rádio. Esta mudança correspondia à tendente mobilidade cultural da vida urbana em Belém, que estabelecia correspondências entre criações artísticas populares e produtos do mercado cultural próximos deste universo. É suficiente lembrar que o setor de entretenimento urbano do Rio de Janeiro, desde os anos 1910, abria espaços de profissionalização para pessoas oriundas dos meios populares e formados musicalmente em rodas de choro, serestas de rua e bandas de música (TRAVASSOS, 2000, p. 12).

O carimbó criado e executado na cidade, nos anos 1930 e 1940, esteve provavelmente inserido nesta atmosfera de apropriação de produtos do mercado cultural pelos criadores musicais locais. As 
toadas de boi gravadas pelos folcloristas da missão paulista tinham traços dos lundus e carimbós presentes nos folguedos populares de Belém, ao mesmo tempo que faziam versões do samba urbano carioca de sucesso nacional à época. Mas interfaces como estas não foram consideradas, no processo de transformação do carimbó, objeto de estudo folclórico ocorrido a partir dos anos 1950.

\section{Os Folcloristas e o Carimbó}

O jornalista cearense Murilo de Menezes, estabelecido em Belém desde fins do século XIX, publicou em 1954 uma crônica muito reveladora do ponto de vista dos literatos locais sobre o contexto sociocultural em que se praticava o carimbó na cidade. Menezes colaborou com diferentes jornais e revistas belenenses escrevendo crônicas sobre folclore regional e impressões de viagem. Trata-se de textos de reminiscências biográficas, cruzadas com temas de natureza sócio histórica. Em 1948, Menezes foi eleito para fazer parte da Academia Paraense de Letras e, na década seguinte, reuniu suas crônicas nos livros Capital do El Dorado, Estudos Contemporâneos e Subindo o Rio Amazonas (MEIRA; ILDONE; CASTRO, 1990, p. 303-304).

A crônica em questão intitula-se Noite de São João e foi publicada no livro A Capital do El Dorado, lançado em 1954 (MENEZES, 1954, p. 80). O texto se reporta à reconstrução memorialística de sua participação numa festa junina no subúrbio de Belém, provavelmente em seu período de adolescência nos anos 1910 ou 1920. Menezes e seus familiares, moradores do bairro de Batista Campos, região central da cidade, foram convidados a participar de uma festa junina familiar no bairro suburbano do Jurunas, promovida por um devoto de São João.

O convite foi feito pela "Donata", apresentada por Menezes como uma "partícula do elemento negroide incrustada com sua quitanda, num bairro de gente branca". Isto destaca no texto o fosso sociocultural mantido ao longo de toda a narrativa entre o mundo dos "brancos de Batista Campos" e o dos “negros e mulatos do Jurunas". Donata sublocava um quarto da residência alugada pela família de Menezes e por isso, talvez, tenha convidado a família dos subsenhorios de sua moradia. Além do mais, a presença de membros de uma família branca de Batista Campos ajudava a prestigiar o dono da festa e cunhado de Donata, carroceiro endinheirado, proprietário de várias carroças e, ainda, homônimo de São João que, por isso, era festejado.

Dos convidados de Batista Campos, só os homens se dispuseram a sair, posto que seria incomum o deslocamento noturno de mulheres de um bairro central para uma festa de subúrbio, na primeira metade do século XX. A caminhada até o local do folguedo é descrita com realce para a mudança da configuração urbana em direção ao subúrbio: surgem no trajeto as ruas "verdes de relva", as "fogueiras", as queimas de fogos, os "grupos boêmios", as casas com reuniões à porta. 
A casa do local da comemoração é descrita como uma "puxada, edificada dentro dum vasto terreno cercado" com um "terreiro limpo" à esquerda, enfeitado com balões e bandeirinhas juninas. A festa era, provavelmente, oportunidade de encontro e celebração para as famílias dos trabalhadores de carroças ligados ao anfitrião.

Chamou também atenção de Menezes, no terreiro, "uma negra esbelta" que "rodopiava horas seguidas com impecável ritmo, ao som de cadenciado batuque”. Em seguida, o batuque foi interrompido pelos "sons de música desencontrados" do boi "Estrela d'Alva" que se apresentou no terreiro e depois foi sucedido pelo cordão junino “Araçari”.

A crônica destaca a presença numerosa de "“pretos e mestiços na festa', que formavam a quase totalidade". ${ }^{11}$ Isso prendeu tanto a atenção do cronista quanto a fartura de alimentos oferecidos aos numerosos convidados. Consumo de comida e dança eram a tônica do evento, animado por uma orquestra de sopro (composta também por rabecão e banjos) nos intervalos de apresentações de grupos juninos. Os momentos de dança eram a oportunidade dos primos e irmãos de Menezes "passarem abraçados com as mais guapas mulatinhas" e de acompanharem com a vista "as pretinhas mais simpáticas".

Segundo o relato, a orquestra tocava polkas para os pares dançantes no terreiro, mas o carimbó era dançado na rua, ao lado da fogueira. Houve também mais uma apresentação de cordão junino, o "Cavalo de Prata", seguida de outra seção musical da orquestra até o encerramento da função às quatro e meia da manhã.

A construção memorialística de Menezes se deu num momento de aparecimento de escritos de literatos e jornalistas que defendiam as "autênticas festas juninas" ainda presentes nas localidades interioranas do estado e no subúrbio de Belém (COSTA; GOMES, 2011, p. 212). O subúrbio, portanto, seria o ambiente característico e apropriado de negros e mulatos promotores de manifestações como bois, cordões e carimbó. Trata-se de uma idealização do mundo suburbano que denota e propõe estranhamento e distanciamento. Isto, por sua vez, reforça o sentido folclórico dessas manifestações.

Em todo caso, a crônica de Menezes é apresentada como um texto sentimental, curiosidade de juventude, de uma cidade que já não seria a mesma dos anos 1950: a polca provavelmente já não era executada nos salões dançantes no subúrbio, e os cordões juninos não seriam tão numerosos na cidade. Por outro lado, a "crônica sentimental" ajudava a posicionar o carimbó como uma manifestação folclórica efetiva nas festas suburbanas de Belém na primeira metade do século XX. Isto não ocorre em textos de temática junina de outros cronistas que publicaram em periódicos belenenses nas décadas anteriores. 
Com efeito, o carimbó viria a ganhar mais e mais espaços nas menções e estudos de jornalistas e folcloristas numa tendência ascendente dos anos 1950 até fins dos anos 1960. Esta produção contribuiu para a formalização, neste período, da visão sobre o carimbó como música regional amazônica por excelência.

Quatro anos após a publicação do livro de Menezes, o jornal A Província do Pará destacou a apresentação de um grupo de carimbó na festa de homenagem (e despedida) ao cônsul norteamericano em Belém, George Colman. A matéria publicada no dia 05 de fevereiro de 1958 informava que a homenagem era uma realização da Comissão Regional de Folclore. Portanto, a principal atração foi apresentada como folclórica: o grupo de carimbó “Conjugado Flor da Cidade”, do município de Marapanim, trazido pelo diretor do jornal Folha do Norte, Paulo Maranhão Filho.

O evento foi realizado no Centro Cultural Brasil Estados Unidos, centro de ensino da língua inglesa associado ao consulado norte-americano no Pará. A homenagem se justificava tanto pela importância política do homenageado quanto por seu envolvimento nos estudos do folclore amazônico. Aliás, a matéria de A Província do Pará intitulava George Colman "um dos incentivadores dos grupos folclóricos de nossa terra".

A apresentação justificava-se. O cônsul norte-americano teve papel importante no desenvolvimento dos estudos de folclore no Pará. Colman foi citado por Abdias Nascimento, ao lado do folclorista Nunes Pereira, como um dos representantes do Pará no I Congresso do Negro Brasileiro, realizado no Rio de Janeiro em 1950 (LEAL, 2011, p. 140). Ele participou também do I Congresso do Folclore Brasileiro realizado no Rio de Janeiro em 1951, em que foram recebidos como representantes do Pará George Colman, José Coutinho de Oliveira, Ernesto Cruz, Margarida Schivasappa, Bruno de Menezes, Nunes Pereira e Levihall de Moura. Colman apresentou o trabalho Os Mistérios das Selvas, e seus colegas representantes do Pará abordaram temas como boi-bumbá (Bruno de Menezes), cordões de pássaro (Ernesto Cruz), linguagem popular (Levihall de Moura) e sairé e marabaixo (Nunes Pereira) (LEAL, 2011, p. 193).

Além do trabalho apresentado no evento, Colman contribuía com as pesquisas de outros folcloristas. No livro publicado por Nunes Pereira, baseado em sua exposição no congresso ( $O$ Sairé e o Marabaixo: tradições da Amazônia), o autor informa ter realizado uma viagem com o cônsul americano ao interior da Amazônia em 1949 com o objetivo de assistir à "dança do marabaixo", praticada no subúrbio da cidade de Macapá (LEAL, 2011, p. 194).

Forma-se então, nesta época, um grupo de interlocução de folcloristas no Pará em torno de temas de pesquisa como expressões lúdicas, festivas e religiosas amazônicas, identificadas pelos pesquisadores como criações negras e mestiças. Ao mesmo tempo, essa produção acompanhava os 
A Produção da "Música Cabocla": a polifonia formadora do Carimbó nas representações de literatos, jornalistas e folcloristas no Pará (1900-1960)

debates desenvolvidos por folcloristas de projeção nacional como Arthur Ramos e Édison Carneiro (LEAL, 2011, p. 209).

Segundo Cavalcanti (2012, p. 111-114), os anos 1950 foram o período em que a área desses estudos alcançou seu apogeu, em torno de um amplo projeto de preservação do folclore nacional. Nesta década, o movimento folclórico construiu uma rede de contatos que envolvia membros das elites intelectuais locais de vários estados brasileiros (CAVALCANTI, 2012, p. 152).

Os estudiosos folcloristas podiam atuar em diferentes frentes de investigação social e, ao mesmo tempo, associar sua tarefa à produção literária ou ao trabalho jornalístico. Trata-se de um período que precede a institucionalização das ciências sociais no País; por isso, suas pesquisas transitavam regularmente entre as abordagens sociológicas e antropológicas. Além disso, o prestígio dos pesquisadores poderia conferir maior visibilidade e reconhecimento social a seus temas e sujeitos de pesquisa.

É o caso da divulgação do carimbó na imprensa quando da homenagem a George Colman. A repercussão do evento incentivou Bruno de Menezes a publicar um comentário sobre a "verdadeira" nomenclatura do Carimbó ("Corimbó") no jornal Folha do Norte, em 13 de fevereiro de 1958. A preocupação de Menezes era quanto ao nome "carimbó", impresso no convite para a homenagem. Segundo ele, “corimbó” é que estava em conformidade com os "termos das gentes do interior”. Mais importante ainda no texto é Menezes ter adicionado uma reflexão sobre as origens negras, indígenas e caboclas do carimbó. A matéria informava que o assunto já fora tratado pelo folclorista em curso de folclore por ele ministrado algumas semanas antes na Academia Paraense de Letras (APL).

Bruno de Menezes voltou a ministrar cursos sobre folclore paraense na APL em 1958 e em 1963, nos quais eram abordados: formação e decadência do lundu no interior do Pará; músicas e danças dos festejos juninos; as características da dança do carimbó e dos cordões de bicho; e modalidades de dança derivadas do lundu que se desenvolveram em diferentes municípios do estado ("Desfeiteira", região de Óbidos; "Marujada e Retumbão", Bragança; "Dança do Peru do Atalaia", em Marapanim) (MENEZES, 1993, p. 345-348, 360). Como síntese de suas reflexões sobre estes temas, Menezes defende a tese da predominância de mestiços (de negros e índios) praticantes destas manifestações folclóricas.

Ao mesmo tempo, a preocupação com a definição das origens destas manifestações perpassa o conteúdo dos cursos ministrados. Destaca-se a tendência a indicar as origens nativas, aborígenes, primitivas das músicas, danças e costumes folclóricos regionais, mantidas em suas sobrevivências/heranças e que afloram na região em algumas localidades no presente.

Esta perspectiva, aplicada especificamente ao carimbó, vinha sendo desenvolvida pelo folclorista Pedro Tupinambá desde 1961. Médico de formação, membro da APL e professor de 
folclore da Faculdade de Filosofia da Universidade Federal do Pará nos anos 1950 (MEIRA; ILDONE; CASTRO, 1990, p. 519), Tupinambá publicou um artigo intitulado Carimbó na Folha do Norte em 05 de fevereiro de 1961, que aprofundava as reflexões de Bruno de Menezes.

O artigo descreve uma apresentação desta música/dança por ele presenciada em Salinópolis (região do Salgado) quando lá estavam seus parentes e amigos durante um "veraneio". O grupo visitou o carimbó de "Seu Elzo", um dos três famosos barracões de festa existentes no município. O texto indica o caráter acidental e episódico do trabalho do folclorista e, ao mesmo tempo, seu feitio de artificialidade, por causa da apresentação previamente organizada para a visita dos veranistas.

A crônica sugere a marcação da distância social entre os espectadores e os participantes: veranistas não dispostos a dançar, batuques como ambientes exóticos e, portanto, inapropriados para mulheres de elite. O artigo apresenta o carimbó, o lugar da dança e da música, como um ambiente de homens e mulheres mestiços. Dançarinos, tocadores e solistas seriam praticantes/executores de uma música indígeno-africana, ligada à natureza da região e à sensualidade feminina, de raízes rurais, mas também com repercussão suburbana.

Relatos como este indicam um distanciamento marcante entre os homens cultos que conheciam as "tradições do povo", militavam por sua preservação, mas não participavam ou não partilhavam do seu universo. O círculo dos literatos e jornalistas, neste caso, assumia a autoridade intelectual de definir critérios de autenticidade para as manifestações folclóricas. Ao mesmo tempo, estes estudiosos demarcavam sua desvinculação pessoal do ambiente dessas "sobrevivências".

Isto corresponde à afirmação de Leal (2011, p. 103) sobre o distanciamento de Bruno de Menezes da condição social de negro. Do ponto de vista de pesquisadores incidentais como Tupinambá, as manifestações musicais e coreográficas de negros e mulatos do interior do estado e do subúrbio de Belém pertenceriam ao mundo do "outro a ser estudado" (LEAL, 2011, p. 213).

Este distanciamento esclarece o ambiente em que se forjou a percepção de folcloristas paraenses dos anos 1960 sobre o carimbó. A dança/música lúdica e folclórica estaria distante daquela dos clubes recreativos e demais salões de dança da capital do estado. Na visão de pesquisadores como Tupinambá, só permaneciam vivas as formas primitivas do carimbó original em alguns rincões ainda alheios a "ritmos estranhos" divulgados pela mídia.

É o que defende o pesquisador Armando Bordallo da Silva (1981) em artigo publicado originalmente em 1959 no Boletim do Museu Paraense "Emílio Goeldi”. Silva era professor de antropologia da Universidade Federal do Pará à época. Sua pesquisa resultou num levantamento descritivo de manifestações folclóricas da região bragantina, no Nordeste Paraense. No capítulo sobre o retumbão, a dança/música típica dos festejos da Marujada da cidade de Bragança, o autor identifica o lundum ${ }^{12}$ como a matriz musical do ritmo bragantino. $\mathrm{O}$ suposto isolamento do retumbão na região, 
A Produção da "Música Cabocla": a polifonia formadora do Carimbó nas representações de literatos, jornalistas e folcloristas no Pará (1900-1960)

"sem ter sofrido as influências da civilização", teria garantido a manutenção de suas "formas primitivas" derivadas do lundum como raiz musical africana (SILVA, 1981, p. 69-70).

Para Silva (1981), o mesmo teria ocorrido com outras formas derivadas do lundum, como o carimbó. A tese da sobrevivência desenvolveu-se de modo pujante neste período e orientou as escolhas dos pesquisadores por seus campos de pesquisa. Por outro lado, nestes mesmos campos, podiam deparar-se os pesquisadores com músicas e danças representativas de "influências da civilização". O próprio Armando Bordallo da Silva relata que as músicas dos barracões, por ele visitados em Bragança, "são as mesmas que qualquer jazz tocaria nas festas da cidade, mas de quando em vez tocam o retumbão". A impressão do pesquisador era que o retumbão chocava-se nos barracões "com os ritmos das danças modernas" (SILVA, 1981, p. 71).

O fato é que estudiosos que referiam a presença das músicas populares no subúrbio de Belém ou no interior do Pará, nos anos 1960, sempre encontravam algo mais que manifestações folclóricas. De Campos Ribeiro (2005, p. 58), em seu livro de memórias sobre Belém escrito em 1966, descreve três festas de mastro do bairro suburbano do Umarizal do início do século $\mathrm{XX}$, com devotos vindos de outros bairros da cidade e com divertimentos de arraial "ao som do carimbó".

A descrição menciona as ladainhas, a decoração do arraial, a busca e o erguimento dos mastros, além dos tabuleiros de comidas e bebidas típicas. O repertório musical, por seu turno, apresentava-se variado. Para além dos carimbós executados por "tristes paus e cordas", aparecem na narrativa "maxixes quebrados" e o elenco musical diversificado de bandas militares (DE CAMPOS RIBEIRO, 2005, p. 58-60).

Mas este fato não chamou atenção do autor. O propósito da obra era exaltar a memória afetiva do escritor sobre sua vida no Umarizal ao longo de 25 anos. Portanto, a "gostosa Belém de outrora" se transforma em discurso de enaltecimento, neste caso, de folguedos populares suburbanos, em que o carimbó encontra um lugar. O livro de De Campos Ribeiro não pretendia fazer qualquer levantamento folclórico, mas sim descrever de forma vívida e atraente "coisas interessantes da vida de Belém”, do que foi presenciado pelo autor (DE CAMPOS RIBEIRO, 2005, p. 07).

Por outro lado, estudos de caráter propriamente folclorista tendiam a demonstrar preocupação com interferências consideradas estranhas às manifestações populares. Exemplo disso é o artigo publicado pelo casal Vicente e Marena Salles, em 1969, sobre o carimbó da cidade de Vigia, localizada na região do Salgado (SALLES; SALLES, 1969). O texto divulgado pela Revista Brasileira de Folclore, quando o próprio Vicente Salles trabalhava como editor do periódico, foi o ponto alto do debate intelectual de pesquisadores no Pará, naquela década, sobre as características folclóricas do carimbó. 
Vicente Salles atuava na Comissão Nacional de Folclore (CNF) desde fins dos anos 1950, a partir de quando integrou a Campanha de Defesa do Folclore Brasileiro (MAFRA, 2012, p. 16). Suas pesquisas, desenvolvidas a partir dos anos 1960, centraram-se especialmente em temas como negro, música e demais expressões folclóricas paraenses, orientadas por um prisma teórico marxista.

Encaixa-se sua produção num novo momento das pesquisas de folclore no País, quando estudiosos ligados ao Movimento Folclórico Brasileiro assumiram como meta a construção de instituições para o estabelecimento do folclore como área de formação acadêmica (VILHENA, 1996, p. 02). A ligação intelectual de Vicente Salles com Édson Carneiro abriu-lhe as portas da CNF e o caminho para uma formação na área de Ciências Sociais (MAFRA, 2012, p. 16).

Os Salles realizaram sua pesquisa de campo em Vigia, no mês de fevereiro de 1968 (SALLES; SALLES, 1969, p. 259). Em acréscimo à perspectiva sociológica de Vicente Salles, o trabalho contou com a contribuição de sua esposa violinista, Marena Salles, ${ }^{13}$ filha do também violinista e compositor Marcos Salles. A musicista era responsável pelas transcrições musicais do que era coletado nos levantamentos de Salles (MAFRA, 2012, p. 74). Sua atuação pronunciada na pesquisa sobre o carimbó da Vigia rendeu-lhe a coautoria no estudo coordenado pelo marido sociólogo e folclorista.

O artigo do casal Salles ajudou a consolidar, partir dos anos 1960, a concepção do carimbó como música típica do caboclo amazônico, associada a sua faina rural e a seus eventos de sociabilidade ritual e festiva. Consagra-se então nos escritos da geração atuante de folcloristas paraenses, a partir dos anos 1960, a invenção do carimbó como expressão musical folclórica típica da Amazônia. Concebo aqui a ideia de "invenção" no sentido desenvolvido por Hobsbawm e Ranger (1984), enquanto produção de novos significados para práticas socioculturais preexistentes em determinados planos de interação social (GONÇALVES, 1996, p. 86).

O texto de Vicente e Marena Salles, assim como crônicas de jornais e revistas publicadas por outros autores no Pará antes de 1969, concorreram para a promoção discursiva do carimbó como manifestação folclórica. A música/dança passava a ser entendida como muito mais grave e representativa da cultura do povo que os brinquedos musicais de festas de santo ou as execuções instrumentais de bandas militares ou conjuntos de "pau e cordas" em bailes dançantes.

A região do Salgado, como vimos, já havia chamado atenção do pesquisador Pedro Tupinambá, especificamente os carimbós de Salinópolis. Aliás, o grupo que se apresentou na homenagem ao cônsul Colman em 1958 era proveniente do município de Marapanim, também localizado na mesma região. Na pesquisa dos Salles, foram indicadas pelos autores semelhanças do carimbó vigiense com aquele descrito por Tupinambá. O artigo, portanto, confirmava (e aprofundava) as impressões sobre o valor folclórico do carimbó difundidas por literatos contemporâneos dos Salles, mas não envolvidos profissionalmente com o Movimento Folclórico Brasileiro. 
Voltamos então à questão lançada algumas linhas atrás: o estudo dos Salles sobre o carimbó ajudou a demarcar a separação entre a "legítima" manifestação folclórica e as apresentações de "projeção folclórica", ou seja, exibições ligadas a promoção turística ou apresentações musicais em bailes dançantes. O texto, inclusive, critica a apresentação do grupo musical de Marapanim em homenagem ao cônsul norte-americano em fins dos anos 1950 como um caso de "projeção folclórica" (SALLES; SALLES, 1969, p. 262).

O carimbó folclórico apresentado pelos pesquisadores seria a música dos "neo-brasileiros" da Amazônia, do tipo mestiço "fundamental" da região, criador do que os autores chamam de “civilização do caboclo" (SALLES; SALLES, 1969, p. 258). Tratar-se-ia então de "música mestiça”, "forma pura do lazer do homem do interior", derivada do antigo lundum (SALLES; SALLES, 1969, p. 259).

Esta é a tese geral de abertura do texto, após o que o artigo percorre os pormenores da pesquisa de campo. A correspondência dos autores com um professor/escritor de Vigia, não nominado, havia aberto as portas para o trabalho de campo. O contato viabilizou a identificação de uma "cantadeira de carimbó" na região rural do município: Francisca Lima do Espírito Santo, também apresentada como a "festeira Tia Pê, promotora de carimbó e outras danças, folias, festas religiosas e promesseiras" no município (SALLES; SALLES, 1969, p. 259 e 263).

Em acordo com Bruno de Menezes, os autores apresentam o carimbó como uma espécie genérica de samba rural (SALLES; SALLES, 1969, p. 262-263). Isso reforça a tese dos autores de que o carimbó deixou de ser dançado em Belém depois de 1900, sendo apresentado em eventos festivos da cidade somente como "projeção folclórica" (SALLES; SALLES, 1969, p. 269). Por isso, sua presença em festejos juninos e carnavalescos da Belém da primeira metade do século XX, por exemplo, não contaria para os autores como manifestação folclórica, dada sua "original ruralidade".

Com efeito, o barracão de Tia Pê, situado na zona rural de Vigia, serviria para os autores como exemplo perfeito de ambiente onde se executava a "música mestiça amazônica". O barracão é descrito como espaço coletivo de festas, para onde convergiam romarias e folias de santo. $\mathrm{O}$ salão era aberto tanto aos devotos que se dirigiam ao oratório lateral como aos dançarinos e espectadores dos bailes dançantes (SALLES; SALLES, 1969, p. 264).

O barracão é apresentado no texto em conjunto com um croqui explicativo. Além do salão, a ilustração destaca o quarto de dormir e a puxada traseira como moradia de Tia Pê. Estes teriam a função mais aproximada de um espaço de privacidade doméstica. Ao lado do barracão, na área externa, o croqui identifica uma tendinha, lugar de venda de bebidas e comidas durante os eventos festivos. A tendinha, então, pode ser apontada como um meio de subsistência econômica da festeira, dada a ocorrência de bailes regulares em sua residência (SALLES; SALLES, 1969, p. 264-267). 
Mas o aspecto de ludicidade das apresentações de carimbó foi o que mais chamou atenção dos Salles. O cuidado dispensado às letras das canções recolhidas em campo direcionou o estudo para a tese da produção/fruição musical como compensação lúdica para o tempo de trabalho (SALLES; SALLES, 1969, p. 267). O interesse pelas canções se sobrepôs ao entendimento das práticas dos sujeitos em campo. De fato, os autores não chegaram a presenciar qualquer evento festivo já programado. A apresentação de carimbó assistida pelos pesquisadores foi organizada em razão de sua presença no barracão e dos contatos que os levaram até a festeira vigiense.

Outras coletas musicais também foram feitas no mesmo momento nos municípios de Salinópolis e Maracanã, ambos da região do Salgado (SALLES; SALLES, 1969, p. 272). Os autores mencionam no artigo o texto de Pedro Tupinambá sobre o carimbó de Elzo Correia, em Salinópolis, o que ajuda a identificar uma matriz folclórica comum da música cabocla paraense (SALLES; SALLES, 1969, p. 271-275).

$\mathrm{Na}$ visão dos autores, o carimbó como samba rural praticado no lazer do caboclo tivera sua matriz musical, coreográfica e religiosa africana diluída, ao ponto de se tornar música de mestiços e "até de brancos" (SALLES; SALLES, 1969, p. 280-281). Este processo, todavia, não é pormenorizado no texto nem discutido em termos históricos, mas sim apresentado como uma evidência eloquente em sobrevivências culturais como os carimbós de Seu Elzo e de Tia Pê.

Mas uma ressalva é feita ao final do texto: o carimbó passava por mudanças mesmo no interior do Pará em face do espraiamento dos meios de comunicação, do acesso à educação e da abertura de estradas (SALLES; SALLES, 1969, p. 280). A advertência aponta transformações do modo de vida urbano na Amazônia, testemunhadas pelos autores quando da execução de projetos desenvolvimentistas na região conduzidos pelos governos militares na década de 1960.

Tais mudanças, sugere esta leitura, tenderiam a alterar o conteúdo de sobrevivências culturais como o carimbó rural, afastando-o de suas matrizes étnicas e folclóricas. Mas o próprio campo de pesquisa dos autores apresentava indicações do papel constitutivo da recriação constante do carimbó em meio a influências musicais e culturais externas. A projeção do carimbó como tradição musical regional, como ocorre com outras manifestações, está ligada às suas possibilidades de adaptação a realidades sociais sempre cambiantes.

Os Salles mencionam a presença de um equipamento de projeção de sonora de carimbó no barracão de Tia Pê, mas não dão muita atenção ao fato. Provavelmente o equipamento fosse usado pela festeira em outros tipos de eventos dançantes por ela organizados (SALLES; SALLES, 1969, p. 266). A sobrevivência econômica da atividade festiva do barracão poderia contar tanto com este tipo de atração musical quanto com as festas em que soavam alto os curimbós de conjuntos vigienses. 
A Produção da "Música Cabocla": a polifonia formadora do Carimbó nas representações de literatos, jornalistas e folcloristas no Pará (1900-1960)

\section{O Carimbó como Música Folclórica}

O carimbó ganhou ampla repercussão midiática no início dos anos 1970 no Pará, vindo a ingressar no mercado fonográfico surgido localmente naquele momento. $\mathrm{O}$ ritmo passou a fazer-se presente tanto em eventos musicais voltados para as camadas médias urbanas (COSTA, 2010, p. 7475) quanto em gravações musicais de artistas de origem interiorana ou suburbana. Oscar de la Torre (2009, p. 146), por exemplo, apresenta a considerável produção de LPs de carimbó nos anos 1970. Segundo o autor, os discos lançados neste período ajudaram a projetar no mercado musical artistas como Verequete, Ely Farias, Alípio Martins, Cadango do Ypê, Grupo da Pesada, Hery Tapajós, Pinduca, Populares de Igarapé Mirim, Vieira e seu Conjunto, dentre outros.

O sucesso midiático e artístico do carimbó manteve, entretanto, íntima ligação com seu caráter folclórico, constituído intelectualmente em debates na imprensa, em textos literários e em escritos acadêmicos. Este sentido foi sustentado pelo cruzamento entre as práticas e as percepções de artistas e aficionados do interior do Pará e do subúrbio de Belém em torno do carimbó e as apreciações de estudiosos no assunto orientadas para o campo do folclore.

A música executada e fruída em festejos de vizinhança, nos brinquedos de cordões carnavalescos, em grupos juninos e em festas de terreiros afrorreligiosos ganhou foros de representatividade sociocultural ao longo do século XX. A invenção intelectual do carimbó como música folclórica acompanhou, neste período, sua disseminação como música de popularidade midiática e se tornou seu elemento constitutivo.

A produção de representações sobre o carimbó revela o lugar social imaginário do intelectual letrado, jornalista e folclorista como "explicador e regente do movimento social": estudar a "música negra" ou "cabocla" reforça esta posição de intérprete da "cultura nacional e regional" (WISNIK, 2004, p. 76). Neste caso, o trabalho dos intermediários culturais testemunha em seu próprio favor (VOVELLE, 2004, p. 224).

A síntese conceitual desta linhagem de estudos e reflexões de literatos, jornalistas e folcloristas consolidou a representação do carimbó como expressão musical mestiça amazônica. Para os autores aqui citados, a música-dança cabocla seria a "autêntica representante" da cultura/identidade nacional no norte do País, derivada da "música negra", quer como batuque afrorreligioso, quer como expressão lúdica (música e dança) primitiva. Assim, tornou-se possível ao carimbó ingressar no caminho do sucesso midiático e dos experimentos de estilização musical.

\section{Referências}


AMARAL, Rita; SILVA, Vagner. Foi Conta para Todo Canto: as religiões afro-brasileiras nas letras do repertório musical popular brasileiro. Afro-Ásia, 34, 2006, p. 189-235.

ANDRADE, Mário de. Música, Doce Música. São Paulo: Martins, 1934.

ANDRADE, Mário. Compêndio sobre a Música Brasileira. São Paulo: I. Chiarato \& Cia. Editores, 1929.

ANDRADE, Mário. Ensaio sobre a Música Brasileira. São Paulo: I. Chiarato \& Cia. Editores, 1928.

BASTOS, Abguar. Flami-n'-Assú. Belém Nova, 15 set. 1927.

BATISTA, Alessandra. Vândalos na Folia: carnaval e identidade nacional na Amazônia dos anos 20. Dissertação (Mestrado em História) - Universidade Estadual de Campinas, Campinas, 2001.

BELMONT, Nicole. Le Folklore refoulé ou les séductions de l'archaïsme. L'Homme, L'anthropologie: état des lieux, t. 26, n. 97-98, 1986.

CAVALCANTI, Maria Laura. Reconhecimentos: antropologia, folclore e cultura popular. Rio de Janeiro: Aeroplano, 2012.

CHAMBOUleyRON, Rafael. Povoamento, ocupação e agricultura na Amazônia Colonial (1640-1706). Belém: Editora Açaí; PPHIST; CMA, 2010.

CHARTIER, Roger. Cultura Popular: revisitando um conceito historiográfico. Estudos Históricos, Rio de Janeiro, v. 8, n. 16, 1995.

CHARTIER, Roger. A História Cultural. Entre práticas e representações. Lisboa: Difel, 2002.

CLIFFORD, James. Sobre o Surrealismo Etnográfico In: A Experiência Etnográfica: antropologia e literatura no século XIX. Rio de Janeiro: Ed. UFRJ, 1998.

CÓDIGO de Posturas Municipais de Belém - 1848, artigo 107, cap. 119: Das Bulhas e Vozeria. Atualizado no Código de Posturas de 5 maio 1880 (Lei n. 1.028).

CORRÊA, Ângela Tereza. História, Cultura e Música em Belém: décadas de 1920 a 1940. Tese (Doutorado em História) - Pontifícia Universidade Católica, São Paulo, 2010.

CORRÊA, João Nazareno. Pilhérias e Tensões do Carnaval Belenense: uma história social dos cordões (1910-1920). Monografia (Graduação em História) - Universidade Federal do Pará, Belém, 2008.

COSTA, Antonio Maurício; GOMES, Elielton Benedito. A "Quadra Joanina" na imprensa, nos clubes e nos terreiros da Belém dos anos 1950: "tradição interiorana" e espaço urbano. Cadernos de Pesquisa do Cdhis, Uberlândia, v. 24, n. 1, jan./jun. 2011.

COSTA, Sérgio. A mestiçagem e seus contrários - etnicidade e nacionalidade no Brasil. Tempo Social; Revista de Sociologia da USP, São Paulo, 13(1), maio de 2001, p. 143-158. 
COSTA, Tony Leão da. Música, literatura e identidade amazônica no século XX: o caso do carimbó no Pará. ArtCultura, Uberlândia, v. 12, vol. 20, jan./jun. 2010, p. 61-81.

DaMATTA, Roberto. Digressão: a fábula das três raças ou o problema do racismo à brasileira". In: Relativizando; uma introdução à antropologia social. Rio de Janeiro: Rocco, 1987.

DE CAMPOS RIBEIRO, José Sampaio. Gostosa Belém de Outrora. Belém: SECULT, 2005.

DE LA TORRE, Oscar. O Carimbó e a História Social da Grande Vigia, Pará, 1900-1950. Amazônicos, v. IV, n. 2, 2009.

DIAS, Robert Madeiro. Em Águas e Lendas da Amazônia: os outros brasis de Waldemar Henrique e Mário de Andrade (1922-1937). Dissertação (Mestrado em História) - Universidade Federal do Pará, Belém, 2009.

DIÁRIO de Belém, 18 set. 1884.

JORNAL Estado do Pará, 13 jan. 1913.

FIGUEIREDO, Aldrin. Letras Insulares: leituras e formas da história no modernismo brasileiro. In: CHALHOUB, Sidney; PEREIRA, Leonardo (orgs.). A História Contada: capítulos de história social da literatura. Rio de Janeiro: Nova Fronteira, 1998.

FIGUEIREDO, Aldrin Moura de. Os Vândalos do Apocalipse e outras histórias: arte e literatura no Pará dos anos 20. Belém: IAP, 2012.

FONSECA, Ribamar. Quando toca o carimbó, ninguém fica parado. Jornal do Brasil, Rio de Janeiro, 1 set. 1975.

GONÇALVES, José Reginaldo. A Retórica da Perda: os discursos do patrimônio cultural no Brasil. Rio de Janeiro: Ed. UFRJ / IPHAN, 1996.

HABIB, Salomão. Tó Teixeira, o poeta do violão. Belém: Violões da Amazônia, 2013.

HOBSBAWM, Eric; RANGER, Terence (orgs.). A Invenção das Tradições. Rio de Janeiro: Paz e Terra, 1984.

LEAL, Luiz Augusto. A Política da Capoeiragem: a história social da capoeira e do boi-bumbá no Pará republicano (1888-1906). Salvador: EDUFBA, 2008.

LEAL, Luís Augusto Pinheiro. Nossos Intelectuais e os Chefes da Mandinga: repressão, engajamento e liberdade de culto na Amazônia (1937-1951). Tese (Doutorado em Estudos Étnicos e Africanos) - Universidade Federal da Bahia, Salvador, 2011.

LEMOS, Rebeca Sarges. Gentil Puget: música na Amazônia e identidade nacional. Monografia (Graduação em História) - Universidade Federal do Pará, Belém, 2012.

MAFRA, Alessandra. O Arauto da Cultura Paraense: uma história intelectual de Vicente Salles. Dissertação (Mestrado em História) - Universidade Federal do Pará, Belém, 2012. 
MANITO, João Jurandir. Foi no Bairro do Jurunas: a trajetória do Rancho Não Posso me Amofiná. Belém: Bresser Comunicação e Produções Gráficas, 2000.

MEIRA, Clóvis; ILDONE, José; CASTRO, Acyr. Introdução à Literatura no Pará. Belém: Cejup, 1990. v. III.

MENEZES, Bruno de. Obras Completas de Bruno de Menezes. Belém: SECULT / CEC, 1993. 3 v.

MENEZES, Murilo. A Capital do El Dorado: crônica sentimental de Belém e comentários sobre alguns dos seus problemas. Belém, 1954.

MIRANDA, Vicente Chermont de. Glossário Paraense (Coleção de Vocábulos Peculiares à Amazônia e especialmente à Ilha do Marajó). Belém: Universidade Federal do Pará, 1968.

MISSÃO de Pesquisas Folclóricas - Carimbó - São Luís do Maranhão, 19 jun. 1938. Vídeo publicado no You Tube por Álvaro Carlini, 03 abr. 2013. Disponível em https://www.youtube.com/watch?v=hjWWVpF-Nlo.

MONTEIRO, Monteiro. Bailado das Três Raças. Belém Nova, n. 76, 30 out. 1927.

MOURA, Carlos Eugênio M. O Teatro que o Povo Cria: cordão de pássaros, cordão de bichos, pássaros juninos do Pará - Da dramaturgia ao espetáculo. Belém: Secult/Pa, 1997.

ORTIZ, Renato. Românticos e Folcloristas: cultura popular. São Paulo: Olho d'Água, 1992.

SALlES, Vicente. Música e Músicos do Pará. Belém: Conselho Estadual de Cultura, 1970.

SALLES, Vicente. A Música e o Tempo no Grão Pará. Belém: Conselho Estadual de Cultura, 1980.

SALLES, Vicente. O Negro no Pará, sob o regime da escravidão. Rio de Janeiro; Belém: FGV; UFPA, 1971.

SALLES, Vicente. Santarém: uma oferenda musical. Belém: Imprensa Universitária, 1981.

SALLES, Vicente. Sociedades de Euterpe: as bandas de música no Grão-Pará. Brasília: Edição do Autor, 1985.

SALLES, Vicente. Bruno de Menezes, era o folclore. In: MENEZES, B. Obras Completas de Bruno de Menezes. Folclore. Belém: SECULT; CEC, 1993. v. 2.

SALLES, Vicente. O Negro na Formação da Sociedade Paraense. Textos Reunidos. Belém: PakaTatu, 2004.

SALLES, Vicente. A Modinha no Grão-Pará: Estudos sobre ambientação e (re)criação da Modinha no Grão-Pará. Belém: SECULT / IAP, 2005.

SALLES, Vicente; SALLES, Marena Isdebski. Carimbó: Trabalho e Lazer do Caboclo. Revista Brasileira de Folclore, v. 1, 9, n. 25, set./dez., 1969.

SCHWARCZ, Lilia Moritz. Complexo de Zé Carioca: notas sobre uma identidade mestiça e malandra. Revista Brasileira de Ciências Sociais, v. 29, n. 10, 1995, p. 49-63. 
A Produção da "Música Cabocla": a polifonia formadora do Carimbó nas representações de literatos, jornalistas e folcloristas no Pará (1900-1960)

SILVA, Anaíza Vergolino. O Tambor das Flores: uma análise da Federação Espírita Umbandista e dos Cultos Afro-Brasileiros do Pará (1965-1975). Dissertação (Mestrado em Antropologia) Universidade Estadual de Campinas, Campinas, 1976.

SILVA, Armando Bordallo da. Contribuição ao Estudo do Folclore Amazônico na Zona Bragantina. Belém: Falângola, 1981.

TONI, Flávia C. Missão: as pesquisas folclóricas. In: Missão de Pesquisas Folclóricas. Música Tradicional do Norte e Nordeste (1938). São Paulo: Secretaria de Cultura de São Paulo, CCSP, SESCSP, 2006.

TRAVASSOS, Elizabeth. Modernismo e Música Brasileira. Rio de Janeiro: Jorge Zahar, 2000.

VELHO, Gilberto. Biografia, Trajetória e Mediação. In: VELHO, Gilberto; KUSHNIR, Karina (orgs). Mediação, Cultura e Política. Rio de Janeiro: Aeroplano, 2001.

VILHENA, Luis Rodolfo. Os Intelectuais Regionais: os estudos de folclore e o campo das Ciências Sociais nos anos 1950. Revista Brasileira de Ciências Sociais. São Paulo, ANPOCS, v. 11, n. 32, 1996.

VINCI DE MORAES, José Geraldo. E "Se você jurar", "Pelo telefone", que estou na "Missão de Pesquisas Folclóricas”? Revista USP, São Paulo, n. 87, set./nov. 2010, p. 172-183.

VOVELLE, Michel. Os Intermediários Culturais. In: Ideologias e Mentalidades. São Paulo: Brasiliense, 2004.

WISNIK, José Miguel. O Coro dos Contrários: a música em torno da Semana de 22. São Paulo: Duas Cidades; Secretaria da Cultura, Ciência e Tecnologia, 1977.

WISNIK, José Miguel. Getúlio da Paixão Cearense (Villa-Lobos e o Estado Novo). In: SQUEFF, E.; WISNIK, J.M. Música: o nacional e o popular na cultura brasileira. São Paulo: Brasiliense, 2004.

\section{Notas}

\footnotetext{
${ }^{1}$ Museu da Universidade Federal do Pará, Acervo Vicente Salles, Pasta: Folclore, Subpasta: Folcloristas.

${ }^{2}$ Os cordões de pássaro e de bichos (de onças, peixes, camarões, caranguejos, etc.) são grupos performáticos compostos por famílias nucleares e seus agregados. Os cordões têm como cerne enredos românticos e melodramáticos, nos quais a trama gira em torno da morte e ressurreição de um animal (como no bumbá). De aspecto fundamentalmente teatral, os "pássaros" e os "bichos" são dotados de forte comicidade assentada na "matutagem", isto é, em cenas engraçadas de matutos que são o ponto alto de empolgação da plateia (MOURA, 1997, p. 35).

${ }^{3}$ Sobre isto ver Chambouleyron (2010).

${ }^{4}$ De Campos Ribeiro começou sua atividade como jornalista nos anos 1920 nas colunas de domingo do diário Folha do Norte e, depois, foi secretário de redação do jornal $O$ Estado do Pará. Tornou-se, neste período, membro da Academia dos Novos e passou então a desempenhar papel destacado no meio literário paraense (DE CAMPOS RIBEIRO, 2005, p. 8).

${ }^{5}$ De acordo com Silva (1976, p. 20), a expressão batuque é usada pelos afrorreligiosos de Belém, desde os anos 1940 , como sinônimo de religiões de matriz africana.

${ }^{6}$ Sobre este assunto, consultar Dias (2009) e Lemos (2012).

${ }^{7}$ A dissertação de Dias (2009) aborda a confluência das obras de Mário de Andrade e do compositor paraense Waldemar Henrique em torno da relação entre produção musical e pesquisa do universo lendário amazônico entre as décadas de 1920 e 1930.
} 


\begin{abstract}
${ }^{8}$ Sobre a relação entre pesquisa musical e o modernismo paulista nos anos 1920, ver: Wisnik (1977).
${ }^{9}$ A primeira edição de Batuque como livro foi em 1931. Somente na edição de 1939 é que vão ser acrescentados poemas novos como Mãe Preta, São João do Folclore e Manjericos e Cavaleiro Jorge. A quinta edição (Editora Falângola), de 1966, foi uma tiragem especial em comemoração aos 350 anos da fundação de Belém.

${ }^{10}$ Exemplo disso é a apresentação de um espetáculo musical pelo compositor e folclorista Gentil Puget no Teatro da Paz, em 1937, de canções em parceria com o escritor e letrista Dalcídio Jurandir. A apresentação musical destacava "motivos do folclore negro" no repertório executado (LEMOS, 2012, p. 26). Puget costumava coletar motivos musicais em terreiros afrorreligiosos de Belém à época, além do que assumiu a liderança do movimento pela liberdade religiosa de 1938 (LEMOS, 2012, p. 28 e 37).

${ }^{11}$ Em seu livro de memórias sobre a Escola de Samba Rancho Não Posso me Amofiná, João Manito, filho de um dos fundadores da agremiação, destaca a recorrência de notas em jornais belenenses dos anos 1940 que descreviam, no período do carnaval, os bairros Jurunas e Pedreira como compostos por negros e/ou "gente cabocla" (MANITO, 2000, p. 54-55).

${ }^{12}$ Palavra grafada pelo autor com o " $\mathrm{m}$ " final: lundum.

${ }^{13}$ Também violinista da Orquestra Sinfônica Brasileira.
\end{abstract}

Antonio Maurício Dias da Costa. Professor Doutor - Faculdade de História - UFPA - Universidade Federal do Pará, Av. Augusto Corrêa, n. 01, CEP: 66075-110, Belém, Pará, Brasil. A pesquisa que resultou neste artigo contou com financiamento do Edital Universal 14/2013, CNPq.

Recebido em 24/02/2015

Aprovado em 27/04/2015 